\title{
Barriers to the Hiring of English Teachers in English Training Schools in Hefei City, China
}

\author{
Issah Iddrisu \\ School of Public Affairs, University of Science and Technology of China, \\ Hefei, Anhui, 230026, China. \\ Tel: +86-18755185009 E-mail: issah@mail.ustc.edu.cn \\ Aigul Islamjanova \\ School of Public Affairs, University of Science and Technology of China, \\ Hefei, Anhui, 230026, China. \\ Tel: +86-18655377002Ｅ-mail: kedy_90@mail.ru
}

Ace Bombaes

School of Public Affairs, University of Science and Technology of China, Hefei, Anhui, 230026, China.

Tel: +86-13865511709 E-mail: bombaes_21@yahoo.com

Dinara Bekbauova

School of Public Affairs, University of Science and Technology of China, Hefei, Anhui, 230026, China.

Tel: +86-18755183292Ｅ-mail: 2501673971@qq.com

Received: January 9, 2017 Accepted: February 14, 2017 Published: February 16, 2017

doi: 10.5296/jsss.v4i2.10573 URL: http://doi.org/10.5296/jsss.v4i2.10573 


\begin{abstract}
English teaching and learning has become an integral part of the Chinese educational system. Due to the opening up policy of the Chinese government to the rest of the world, the need to reform in line with the changing demands of the time became necessary. This therefore led to the influx of potential foreign English teachers in to the country due to the demand for foreign English teachers. The study therefore explores the factors influencing the hiring decisions of potential foreign English teachers in Hefei. Questionnaire was used to elicit information from respondents with the help of SPSS as the analysing tool. Using logistic regression model it made it possible to better understand the impact of the factors that influence hiring decisions. Results indicated that gender and experience were statistically significant. Colour and educational level were not statistically significant but important in the hiring decisions. Nationality of a potential foreign English teacher was not significant and also not important in the hiring decisions. The study concludes that professional recruiters should be put in place during the hiring process. It therefore suggests that competence should be a key factor in the hiring decisions of potential foreign English teachers in order to better learner's outcomes and to meet the objective of the state.
\end{abstract}

Keywords: Foreign English teacher, Hiring decisions, Barriers, Recruiters

\title{
1. Introduction
}

The queen's language (English) is widely spoken throughout the world today. It is also by practice the most dominant language in the world. It has also become the most influential among all languages which breaks all barriers. It permeates all fields as well. This has led to the realization that without English in ones endeavours he or she can be left out of the global stage. In order to be placed at the centre of world affairs after decades of isolation, the Chinese government put up a state policy of opening up the country to the rest of the world. This was to enable the country actively participate and stir affairs at the world stage. To achieve this meant the development of well trained citizens to be able to communicate well the government's foreign policy to the rest of the world. The English language was accepted and made compulsory as part of the Chinese educational reform from 1978 till date. Since then, the English language has become the most dominant foreign language in China (Chen, 2011).

The dominance of the English language started about four to five decades ago (Close, 1981). This led to the adoption by many countries as their official languages and others as their second national language. Many criticise the dominance of the English language as having an effect on their local language. This was the case in a work conducted in Japan by Kubota, (1998). He concluded that English is necessary but there should be a deliberate promotion of national values with an inclusion of competent English skills in the learning process.

This dominance permeated in to every society throughout the world (Melitz 2016). It also came with a huge cost to many governments. In the Chinese society, there has been a lot of funding into the design of curriculum, infrastructure and hiring of foreign English teachers to meet the demands of the state (Huang, 2010). With the tremendous increased in funding by 
the Chinese government, student outcomes do not meet the expectations of the state $(\mathrm{Hu}$, 2014)). After years of study many students do not live up to the desired expectation. This indicated a shortfall in the design and implementation process of acquiring English as a foreign language. It could emanate from the design of the curriculum to the hiring of the right professionals to implement the designed curriculum.

The study focused on teacher hiring decisions and the factors that are considered in hiring a good foreign English teacher. It is stated that with a competent teacher outcomes of students will improve. The study will contribute to the little work done in this area. It will also help shape the policy of the state desire in achieving its objective of improving student's outcomes in the learning of the English language. The study therefore explored the factors considered in hiring the services of a foreign English teacher in Hefei. There is a rush by prospective foreign English teachers for English teaching jobs in China. This might be due to better conditions of service, increased in the number of English training schools and the readiness of parents to pay for their children to learn. The study also put forward suggestions on best possible hiring decisions to better improve the outcomes of learners.

\section{Relevant Literature}

With rapid industrialization and expansion in all facets, China developed the opening up policy. This led to the opening up of the country to the international community. It also led to a number of reforms and the influence of the world dominant language (English language) in the daily lives of people in China (Rao, 2013).

English has become the most dominant foreign language in China since 1978 (Jiang, 2016). It has become the household word. Many households prefer to send their children to English speaking schools. It is estimated that there are 440-650 million English learners and users in China (He \& Zhang, 2010). This is in relation with the high population of the country and the influx of foreigners. It is also considered the largest English learning and using population in the world (Gao, 2007, Gupta, 2006). Almost all Chinese will like to learn to write and speak English. Those who don't have the opportunity to learn English try to speak with foreigners on the street to improve their English skills.

In an effort to boost the learning of the English language, the government made it compulsory at all levels in China. To support this policy, the government increased funding for the development and delivery of the English curriculum. There has being the development of the national English teaching guidance by the ministry of education in 2001. This was to support the effort of government in initiating a strategy for the development of the English language. With all these efforts by government, student outcomes do not meet the government expectations. (Huang, 2010, Wang, 2014, Zhang, 2008)

In other studies, it is suggested that the learning environment, the language teacher's competence and the learner's themselves are key in the teaching and learning process. (Allon-Soler, 2005). This indicates how important it is in incorporating the factors such as environment, the teacher and the learner to achieve a better outcome in the learning process. It therefore puts to play the issue of policy formulation and implementation. What policies 
are formulated and how should they be implemented. The study therefore looks at the policy implementation gap and how that has been exploited.

\subsection{Analytical Framework}

Many policies are formulated without guidelines for its implementation. This act always creates a gap for policy implementers to deal with. In dealing with such policy gaps, implementers always have their way during the implementation process. The conflict theory best explains this scenario. The theory stipulates that many policies have a vague language. The policy language does not spell out the implementation mechanisms for implementers to follow. It therefore gives policy implementers the flexibility to incorporate their own ideas into the implementation process. Cohen et al. (2005) believe that policy makers intentionally create this vague policy implementation language. This gives way for policy implementers to have their way during the implementation process. To fill the gap during the implementation process, policy implementers develop their own mechanisms to fulfil the policy.

The hiring of foreign English language teachers in China has a policy implementation lapse in many of the English training schools. There exists a policy allowing English training schools to hire the service of foreign English teachers. The matter of who should be hired remains in the domain of the school concern. The government in a recent policy outlined the criteria for the hiring of foreign English teachers in some selected cities. This policy is yet to be implemented. This policy is also said to apply to big cities which include Beijing, Shanghai, Shenzhen and Guangzhou. In Hefei all English training schools have their own criteria for hiring foreign English teachers. The policy in place for the hiring of foreign English teachers in China gives the right to hire and who to be hired in the hands of training schools to take their own decisions dependant on their own conditions. Hiring based on your own condition therefore confirms the claim by Cohen's et tal (2005).

\section{Methodology}

The study was done in Hefei, in the Anhui province of China. It was done with a sample size of fifty-five (55) participants. Participants were selected from various English training schools. The nature of the sample was due to the number of English training schools in the city. The city is considered to be among those recently being opened to foreigners. The city is attractive to foreigners seeking employment opportunities. Parents hire foreign English teachers to teach their children at home, but our focus was on formal English training schools in the city. Participants included those involved in the recruitment or hiring of foreign English teachers. The variables considered in the study were chances of getting the English job as the dependant variable. The independent variables were gender, education, colour, experience and nationality of potential foreign English teachers.

A questionnaire was used to gather data and analysed with the help of SPSS software version 23. The logistic regression model was used to find out whether the independent variables identified really have an impact on the dependent variable. We did the regression of our independent variables on the dependent variable. Due to the analytical tool chosen for the study, our dependent variable was coded in a binary form. With the nature of the city, 
dispersed location of various English training schools and timings of their training sessions, it was very difficult to get the target group to participate in the research. With the motivation of the team it was possible to accomplish the task.

\section{Results}

Table 1. Classification Table

\begin{tabular}{lllll}
\hline Observed & & No Job & getting Job & \%Correct \\
\hline Job & No job & 27 & 6 & 81,8 \\
Acceptance & Getting Job & 9 & 13 & 59,1 \\
Overall Percentage & & & $\mathbf{7 2 , 7}$ \\
\hline
\end{tabular}

a. The cut value is ,500.

Table 1 summarizes the model of the predicted variables. The prediction is that the chance of getting the English teaching job considering all the independent variables is $72.7 \%$. This indicates that there is a high chance of getting the English teaching job holding all the variables in place. Potential foreign English teachers in the city of Hefei have a chance of getting the job if they apply.

The impact of each variable on the chances of getting the English teaching job therefore differed. The individual variable effect is depicted in the following table.

Table 2. Variables in the Equation

\begin{tabular}{llllllll}
\hline & & B & S.E & Wald & df & Sig & Exp(B) \\
\hline Step 1 & Edu &, 737 & 540 & 1,867 & 1 & 172 & 2,090 \\
& Nation &,- 190 & 309 &, 378 & 1 & 539 &, 827 \\
& Gender & 1,537 & 643 & 5,717 & 1 & 017 & 4,652 \\
& Color &, 963 & 748 & 1,657 & 1 & 198 & 2,618 \\
& Exp & 1,354 & 665 & 4,153 & 1 & 042 & 3,874 \\
& Constant & $-4,207$ & 1,568 & 7,196 & 1 & 007 &, 015 \\
\hline
\end{tabular}

a. Variable(s) entered on step 1: Edu, Nation, Gender, Color, Exp.

From Table 2, education is not statistically significant. On the other hand education is considered important in the hiring decisions of potential foreign English teachers. Within the level of education bracket, there is a higher chance for those with educational level from twenty (20) years and above of getting the job then those with lower educational levels. Therefore the education level of a potential foreign English teacher is considered important in the hiring decisions of recruiters. 
Nationality is represented on the table as nation as an independent variable. It is not significant in the hiring decisions of recruiters. It is negative which indicates that there is a chance for all nationalities dependent on the availability of the job at a time. The more the nationality that applies for the job at a time, the more their chance of getting the job.

The table also indicates that gender is highly significant. The significance level is at 0.017 . Gender in this sense plays an important role in the hiring decisions of recruiters in the city of Hefei. The results therefore show that males are more preferred or have the chance of getting the job than female. This preference might be due to the non availability of female foreign teachers. Female foreign teachers are observed not to stay long on the job when given the opportunity. This therefore influences most recruiters for the preference of the male sex.

Another independent variable considered was the colour of a potential foreign English teacher. From the results the colour of a potential foreign English teacher is not statistically significant but important. The model indicates that white skin applicants have a higher chance of getting the job than others. The perception of most recruiters based on colour is attributed to their lack of knowledge on the ability of black people. Many hold the view that most or all black people do not speak good English. The notion which also holds in the city among many recruiters is that native English speakers are all whites. This perception of recruiters therefore influences their hiring decisions.

The fifth independent variable considered in the study was the experience of a potential foreign English teacher. The model predicts that experience is highly significant. The significance level is at 0.007 . This means the experience of a potential foreign English teacher plays an important role in his hiring decision. It also means that the higher the experience the higher his chance of getting the job. In this case people with six years and above of experience have the higher chance of getting the job than those with lower years of experience.

\section{Conclusion}

The decision or power to hire a foreign English teacher is in the hands of the English training school concerned. If schools are able to make good decisions in the hiring process, it will help improve the performance of the students (Boyd et al., 2011). In the work of Chacón (2005) in Venezuela, explains how teacher efficiency can impact on the performance of students. Policy implementation measures therefore need to be put in place to outline who should be considered for the job. The state therefore needs to have criteria of selection during the hiring of foreign English teachers.

Based on the study, gender and experience are statistically significant. These two variables confirm the assumption that they are an integral part of the hiring decisions of recruiters. The educational level and the colour of potential candidates are not statistically significant but important in the hiring decisions of candidates. The findings is also supported in the work of Carlsson and Rooth (2008). Their conclusion supports the assumption of the current study. It also explains how discriminatory it is in the hiring decisions of recruiters during the hiring process. 


\section{MInstitute Macrothin}

The study also found out that nationality of potential candidate though not significant but important in the hiring decisions. It makes it possible for effective school to hire best performing teachers. It is also possible for effective schools to hire the services of better teachers from non performing schools (Loeb, Kalogrides, and Beteille 2012). It therefore shows how open the chance is given the availability of the job without nationality being a factor. This factor was evident during the study in which diverse nationalities were present at the various English training centres.

Though some research has been done on this topic in different perspectives, much of the research done generalizes the variables. This can be seen in the work of (Boyd et al. 2011; Liu, Johnson, and Liu 2006; Mason and Schroeder 2010). They looked at hiring decisions in a general perspective without narrowing it to individual variables. The current work therefore takes a careful look at the various variables and their relative impact on the hiring decisions of various recruiters. This makes our current work different from the previous works done so far.

\subsection{Recommendations}

Based on the study so far the following are put forward to better enhance the hiring decisions of recruiters. This will also better the outcomes of learners in order to meet the expectations of the state.

- Identification of the necessary competencies: potential foreign English teachers should be recruited based on their competence not on the variables indentified with the exception of level of education and experience.

- Identifying and addressing the potential biases among interviewers: recruiters should avoid biases towards potential foreign English teachers. They should not be recruited based on colour, gender and nationality which is already identified as not significant in hiring decisions.

- Applicants should be provided every opportunity to demonstrate their necessary competencies: potential foreign English teacher all have varied potentials. There is therefore the need to experience these varied skills in order to make a hiring decision.

- The state should provide a guideline for all to follow and also make an adjustment to individual cities. Due to the level of development and openness to foreigners.

The human resource needed to effectively achieve the goal of the state does not only rest on the hiring decisions of recruiters. The state needs to take an urgent action to attract the best professionals in the hiring process. When recruitment professionals are in place, effective and efficient professional teachers will be hired to implement the objective of the state.

\section{References}

Alcón Soler, E. (2005). Does Instruction Work for Learning Pragmatics In the EFL Context? System, 33(3), 417-435. https://doi.org/10.1016/j.system.2005.06.005

Boyd, D., Lankford, H., Loeb, S., Ronfeldt, M., \& Wyckoff, J. (2011). The Role of Teacher 
Quality in Retention and Hiring: Using Applications to Transfer to Uncover Preferences of Teachers and Schools. Journal of Policy Analysis and Management, 30(1), 88-110. https://doi.org/10.1002/pam.20545

Carlsson, M., \& Rooth, D.-O. (2008). Is it your Foreign Name or Foreign Qualifications?: An Experimental Study of Ethnic Discrimination in Hiring. Iza, (3810)

Chacón, C. T. (2005). Teachers' Perceived Efficacy Among English as a Foreign Language Teachers in Middle Schools in Venezuela. Teaching and Teacher Education, 21(3), 257-272. http://doi.org/10.1016/j.tate.2005.01.001

Chen, L. (2011). National Foreign Language Strategies in the New Century. Journal of Foreign Languages. No.2, 16-28. Shanghai: Shanghai Foreign Language Education Press.

Close, R. A. (1981). English as a World Language and as a Mother Tongue. World English's, 1(1), 5-8. http//doi.org/10.1111/j.1467-971X.1981.tb00439

Cohen, A., Timmons, J. C., \& Fesko, S. L. (2005). The Workforce Investment Act: How Policy Conflict and Policy Ambiguity Affect Implementation. Journal of Disability Policy Studies, 15(4), 221-230. https://doi.org/10.1177/10442073050150040401

Gao, L. (2007). Chinese English's: A Sociolinguistic History (Review). Language, 83(2), 455-455. https://doi.org/10.1353/lan.2007.0068

Gupta, A. F. (2006). Kingsley Bolton: Chinese English's: A Sociolinguistic History. Cambridge University Press, Applied Linguistics, 27(1), 145-147. https://doi.org/10.1093/applin/ami044

He, D., \& Zhang, Q. (2010). Native Speaker Norms and China English: From the Perspective of Learners and Teachers in China. TESOL Quarterly, 44(4), 769-789. https://doi.org/10.5054/tq.2010.235995

Hu, Z. (2014). Study on Developing Chinese College EFL Learners' Pragmatic Competence in Relation to Language Proficiency and Overseas Experience. Journal of Language Teaching and Research, 5(2). https://doi.org/10.4304/jltr.5.2.391-398

Jiang, Y. (2016). A Study on the Features of Pre-Service English Teachers' Reflection. A Study on Professional Development of Teachers of English as a Foreign Language in Institutions of Higher Education in Western China, 43-65.

Kubota, R. (1998). Ideologies of English in Japan. World English's, 17(3), 295-306. http://doi.org/101111/1467-971X.00105

Liu, E., Johnson, S. M., \& Liu, E. (2006). New Teachers' Experiences of Hiring: Late, Rushed, and Informatin-Poor. Educational Administration Quarterly, 42(3), 324-360. http://doi.org/10.1177/0013161X05282610

Loeb, S., Kalogrides, D., \& Beteille, T. (2012). Effective Schools: Teacher Hiring, Assignment, Development, and Retention. Education Finance and Policy, 7(3), 269-304. https://doi.org/10.1162/EDFP_a_00068 


\section{Macrothink}

Journal of Social Science Studies

ISSN 2329-9150 2017, Vol. 4, No. 2

Mason, R. W., \& Schroeder, M. P. (2010). Principal Hiring Practices: Toward a Reduction of Uncertainty. The Clearing House, 83(5), 186-193. http://doi.org/10.1080/00098650903583727

Meltiz, J. (2016). 'English as a Global Language' In the Palgrave Handbook of Economics and Language. pp. 583-615

Rao, Z. (2013). Teaching English as a Foreign Language in China: Looking Back and Forward. English Today, 29(03), 34-39. https://doi.org/10.1017/S0266078413000291

Wang, Z. (2014). Developing Accuracy and Fluency in Spoken English of Chinese EFL Learners. English Language Teaching, 7(2). https://doi.org/10.5539/elt.v7n2p110

Zhang, H. (2008). Strategies on how to help Chinese Students Walk out of Deaf and Mute English. China Education Innovation Herald, 23, 22-23.

Zheng, L., \& Huang, J. (2010). A study of Chinese EFL Learners' Pragmatic Failure and the Implications for College English Teaching. Polyglossia, 18, 41-54.

\section{Copyright Disclaimer}

Copyright for this article is retained by the author(s), with first publication rights granted to the journal.

This is an open-access article distributed under the terms and conditions of the Creative Commons Attribution license (http://creativecommons.org/licenses/by/3.0/). 